\title{
Trouble Shooting during Heavy Leakage from Urea Plant HP Loop
}

\author{
Prem Baboo \\ National Fertilizers Ltd. India
}

\begin{abstract}
In high Pressure Urea reactor, sudden pressure drop by any reason can cause bulging of liner. In any reason (heavy leakage in HP section of urea plant, PSV popped etc.) the HP loop pressure goes to zero, then how to drain out urea /carbamate solutionfrom HP loop without pressure to take shut down.At gravity, it is very difficult to drain out urea solution from $1 \frac{1}{2}$ "line and also huge amount of effluent generation. the urea reactor is a typical gas liquid urea and ammonium carbamate reactor involving not only back mixing phenomenon but also significant aspect of heat and mass transfer between high corrosive vapors and liquid phase.Urea Reactorcontaining about 34-35 \% Urea,33-34 \% ammonia, $14 \% \mathrm{CO}_{2}$ and rest is water.In $\mathrm{M} / \mathrm{S}$. saipem process all the safety has been taken in account e.g.to protect the reactor in case a sudden pressure increases an automatic system has been providedwith interlocks to stop the fluid inlet feed. The temperature profile is progressively rising inside the reactor due to density variation. In this article, all procedure described at zero $\mathrm{kg} / \mathrm{cm}^{2}$ pressure Feed in in Urea reactor as well as draining of urea solution to take shut down and how to manage effluent generation at draining of HP loop. The experienced gained when our 31 stream HP loop PSV-2(HP loop Carbamate separator PSV) sudden popped with heavy leakage from upstream flange of PSV-2 on dated 11/10/2018 at 11.50 hrs. and pressure of HP loop went to zero $\mathrm{kg} / \mathrm{cm}^{2}$.At that time the plant was running on full and constant load.
\end{abstract}

Keywords - Reactor Feed in, Reactor Draining, effluent generation, Safety hazards, trouble shooting, Pressure safety valve, corrosion.

\section{INTRODUCTION}

National Fertilizers Ltd, (NFL) operates a fertilizer complex at Vijaipur, Distt. Guna (Madhya Pradesh), India consisting of two units Vijaipur-I and Vijaipur-II, plants were commissioned in December 1987 and March 1997 respectively. Ammonia Plants are based on M/s. HTAS's Steam Reforming of Natural Gas and Urea plants are based on M/S. Saipem's Ammonia Stripping technology. NFL, a
Schedule 'A' \& a Mini Ratna (Category-I) Company. The Vijaipur unit, which is an ISO 9001:2000 \& 14001 certified, comprises of two streams. The Vijaipur have two ammonia plant M/S. Haldor Topsoe Technology, Denmark capacity $1750 \& 1864$ TPD for Line-I \& line-II respectively and four urea plant of $\mathrm{M} / \mathrm{S}$. Saipem ammonia stripping process, Italy. The capacity of Urea-I urea -II is 3030 \& 3231 TPD respectively. The raw material used includes natural gas, water and power. Three Numbers Captive power plant of capacity 17 X $3 \mathrm{MW}$ are used in this complex. The Complex manufactured about 2100000MT urea per annum.The emergency situations which are likely to arise are several and extremely variable as to duration and seriousness. Considerable pressure and /or temperature increases Pipe line clogging because of crystallization. Sudden failure of services like PSV, flanges leakage failure of equipment's Fires, and / or ruptures with uncontrollable losses of toxic gasses.The evaluation of the seriousness of an emergency situation and therefore the decision of how to shut the plant down is a matter of the operators' experience. He should take prompt and corrective action.However, the inter lock system is designed to minimize the number of manual operations.

Description of incident

On dated 11/10/2018 at $11.50 \mathrm{hrs}$ the 31 stream was running on full load sudden loud sound heard and ammonia cloud observed near HP carbamate vessel. The PSV -2(mounted on HP carbamate separator vessel was popped and during popping upstream flange got heavy leakage of ammonia/carbamate as shown in the fig- $2,3 \& 4$ as trends of pressure drop .Immediately shut down of 31 stream was takenand control the situation. Now problem arise how to drain out the HP loop solution to arrest the leakage from the PSV? However, no casualty was there. 


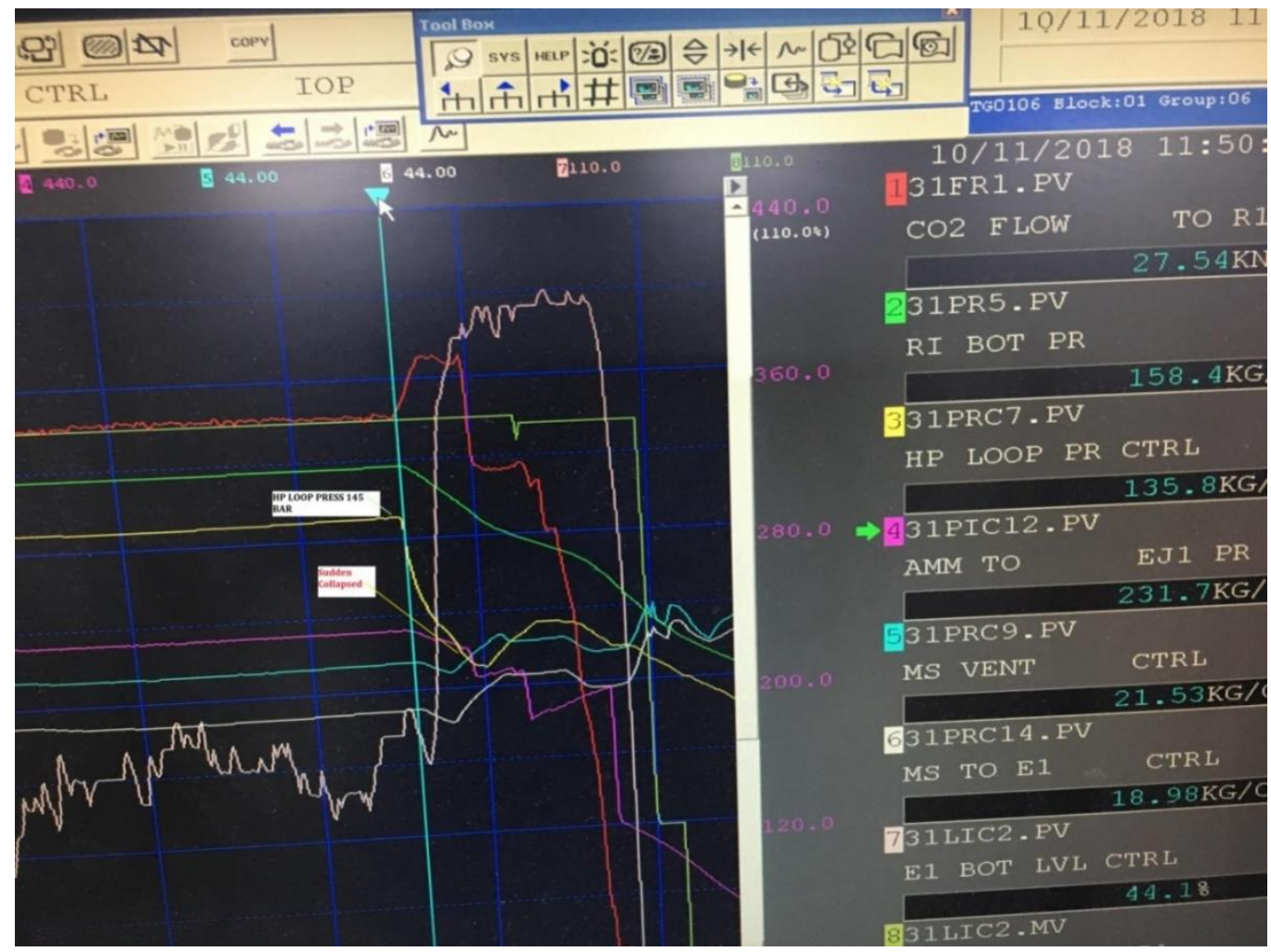

Fig-1(trends of Pressure when safety popped)

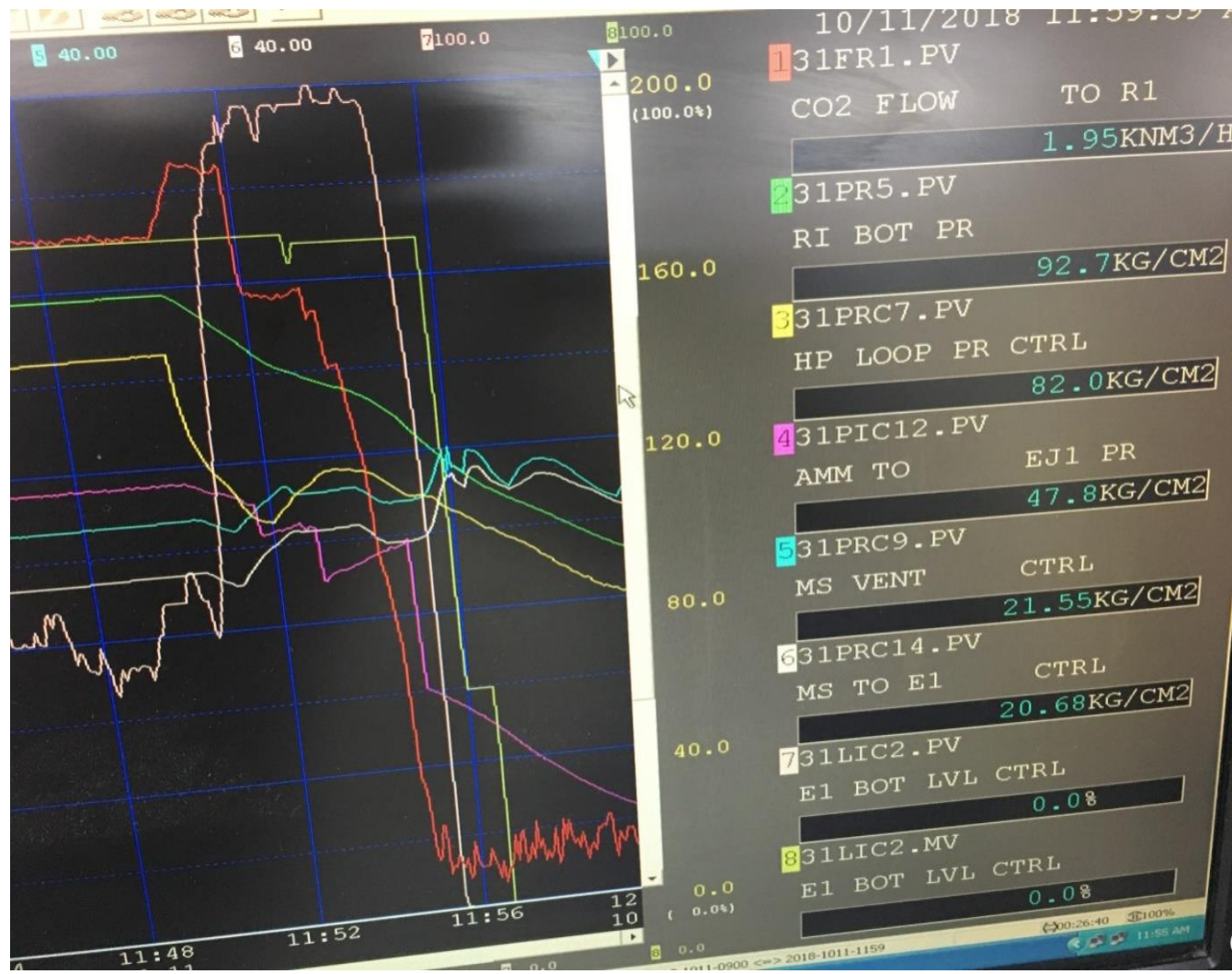

Fig-2(Trends of parameters when safety popped) 


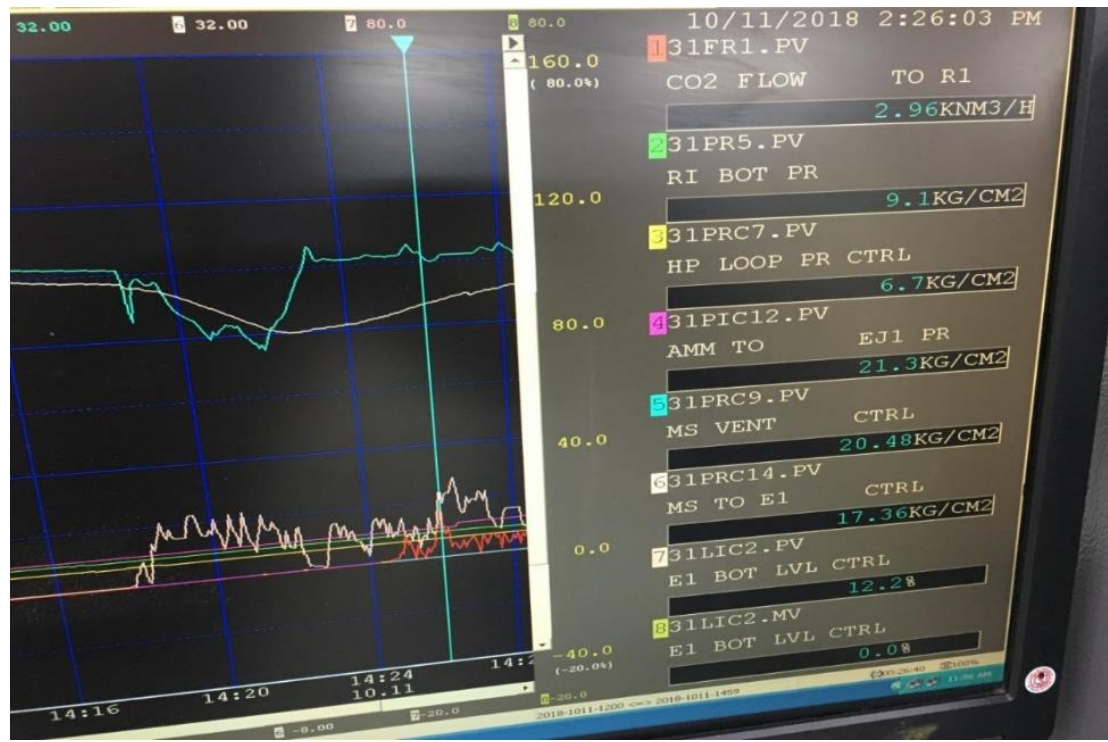

Fig-3(Trends of Parameters when safety popped)

HP loop form the centre of any urea plant. High pressures and temperatures, the corrosiveCircumstances and the health risks of ammonia in case of a leak put high demands to the integrity of such a vessel. At that condition anything could have happened, e.g. bulging of liner, leakage from weep holes, damage of liner, chances of casualty if the people were working there.

\begin{tabular}{|l|l|l|l|l|l|l|}
\hline Sr. No. & Parameters & $11.50 \mathrm{hrs}$ & $12.00 \mathrm{hrs}$ & $12.10 \mathrm{hrs}$ & $12.20 \mathrm{hrs}$ & $12.30 \mathrm{hrs}$ \\
\hline 1 & $\begin{array}{l}\text { HP Loop Pressure (PIC } \\
\left.\text { 07)(kg/cm }{ }^{2}\right)\end{array}$ & 135 & 110 & 66 & 25 & 4 \\
\hline 2 & $\begin{array}{l}\text { Reactor } \\
\text { Temperature }{ }^{0} \mathrm{C} \text { bottom }\end{array}$ & 166 & 144 & 124 & 121 & 110 \\
\hline 3 & $\begin{array}{l}\text { Reactor Top Temperature } \\
\mathrm{C}\end{array}$ & 184 & 157 & 133 & 129 & 116 \\
\hline
\end{tabular}

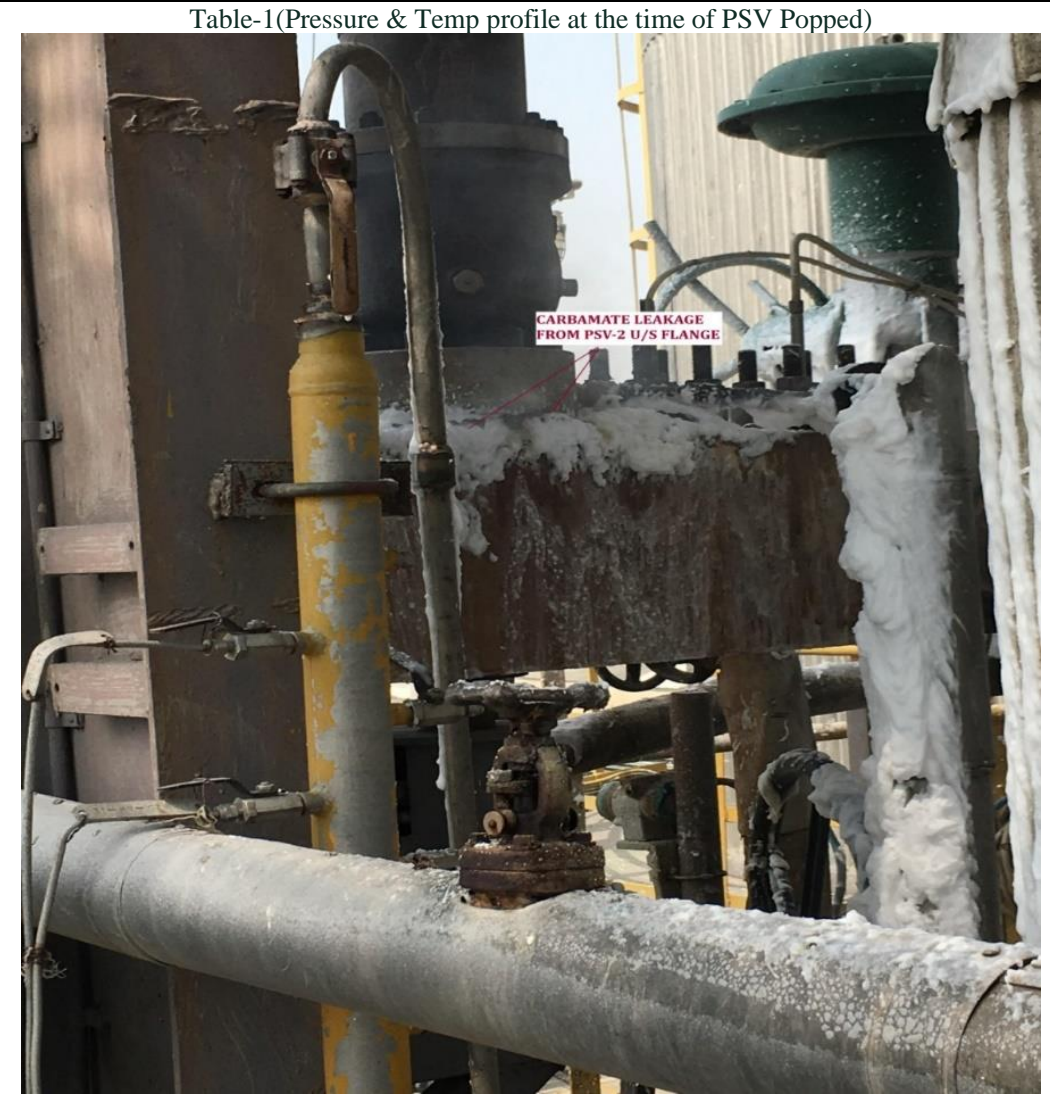

Fig-4(Vapour \& liquid, carbamate leakage from PSV-2) 
As it is well knowing the modern urea processes are recycle type of process, therefore a temporary or sudden inefficiency of the synthesis loop, or more in detail of the urea reactor, would have a significant impact on the overall urea plant performances and under certain conditions may even lead to a plant shutdown. One of the challenges in operating a urea plant is to combat the corrosive process environment in the High-pressure vessel in synthesis section.

After long discussion the decision was taken the upstream flange got tightened and PSV to be

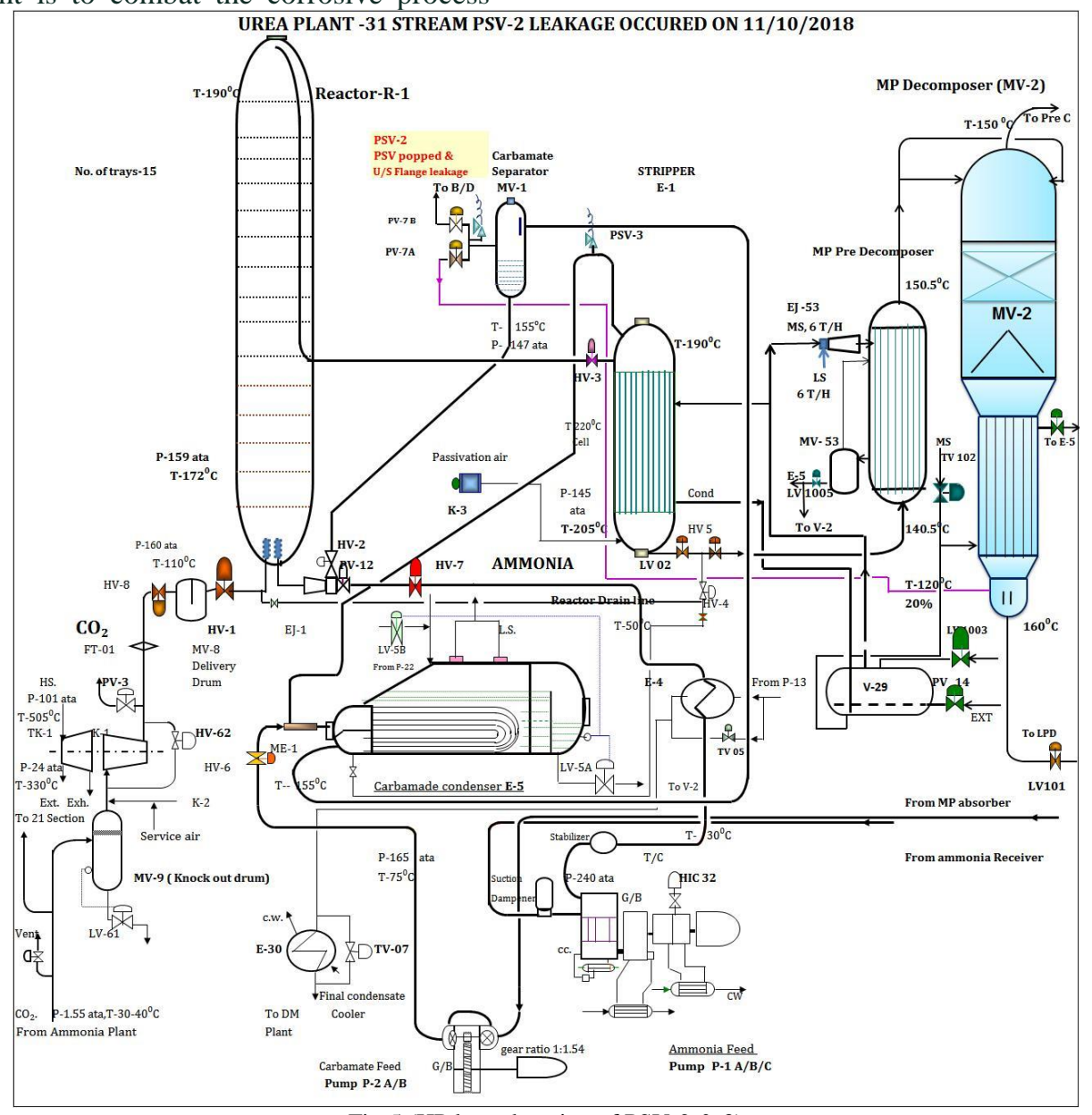

Fig-5 (HP loop, location of PSV-2 \& 3)

Gaged. By using all safety equipment's (on line air mask, face shield etc.) the upstream flange of PSV -2 got tightened and PSV-2 gaged. Now for safety point of view this PSV was useless and fully depended on PSV-3(mounted on stripper vapors line).As the HP loop having two PSV one mounted on carbamate separator and other on stripper vapor line. Now problem of how to feed at zero $\mathrm{kg} / \mathrm{cm}^{2}$ pressure?
Now there are two option of filled reactor feed in at zero $\mathrm{kg} / \mathrm{cm}^{2}$ pressure.

1. The HP loop pressurized by ammonia start up line using jacketing steam.

2. First feed ammonia to reactor and after getting about $50 \mathrm{~kg} / \mathrm{cm}^{2}$ pressure $\mathrm{CO}_{2}$ to be feed.

\begin{tabular}{|l|l|l|l|l|l|l|}
\hline Sr. No. & $15.00 \mathrm{hrs}$ & $15.30 \mathrm{hrs}$ & $16.00 \mathrm{hrs}$ & $16.30 \mathrm{hrs}$ & $17.00 \mathrm{hrs}$ & $17.30 \mathrm{hrs}$ \\
\hline $\begin{array}{l}\text { Ammonia Feed in, } \\
\mathrm{m}^{3} / \mathrm{hr} .\end{array}$ & 20 & 25 & 25 & 37 & 45 & 58 \\
\hline $\mathrm{CO}_{2}$ Feed in, $\mathrm{NM}^{3} / \mathrm{hr}$. & 0 & 0 & 6800 & 9950 & 12000 & 15000 \\
\hline $\begin{array}{l}\text { Reactor pressure } \\
\mathrm{kg} / \mathrm{cm}^{2}\end{array}$ & 0 & 20 & 38 & 57 & 92 & 142 \\
\hline $\begin{array}{l}\text { Reactor Top } \\
\text { Temperature }{ }^{0} \mathrm{C}\end{array}$ & 116 & 129 & 155 & 178 & 183 & 190 \\
\hline $\begin{array}{l}\text { Reactor Bottom } \\
\text { Temperature }{ }^{0} \mathrm{C}\end{array}$ & 110 & 122 & 144 & 166 & 169 & 173 \\
\hline
\end{tabular}

Table-2(Pressure \& temp profile when reactor Feed at zero $\mathrm{kg} / \mathrm{cm}^{2}$ pressure) 
In normal start up or feed in to the empty reactor is simple. The HP loop pressure increases by ammoniation at the rate of $30 \mathrm{~kg} / \mathrm{cm}^{2} / \mathrm{hr}$. The dedicated system is installed with pipe heat exchangers the ammonia pipe heated with 24 bar steam outside jacketed provision. The pipe is sufficient long so that the ammonia heated by this line about $150^{\circ} \mathrm{C}$. when the pressure achieved about $90-100 \mathrm{~kg} / \mathrm{cm}^{2}$ and temperature $150^{\circ} \mathrm{C}$, The Feed in of $\mathrm{CO}_{2}$ and Ammonia through inlet main line to be fed.

But in present case the reactor is filled of liquid fluid with zero $\mathrm{kg} / \mathrm{cm}^{2}$ pressure and temperature about $120^{\circ} \mathrm{C}$. Whenever start up to be performed with the filled reactor at zero $\mathrm{kg} / \mathrm{cm}^{2}$ plant and about $120^{\circ}$ temperature equipment

\begin{tabular}{|c|c|c|c|c|c|}
\hline $\begin{array}{c}\text { Plant Load } \\
\%\end{array}$ & MTPD & $\begin{array}{l}\mathrm{CO}_{2} \mathrm{TO} \mathrm{R}-1 \\
\left(\mathrm{NM}^{3} / \mathrm{HR}\right)\end{array}$ & $\begin{array}{c}\mathrm{NH}_{3} \mathrm{~T} 0 \mathrm{R}-1 \\
\left(\mathrm{M}^{3} / \mathrm{HR}\right)\end{array}$ & P-1 (RPM) & $\begin{array}{c}\mathrm{NH}_{3} \text { FROM BL } \\
\left(\mathrm{M}^{3} / \mathrm{HR}\right)\end{array}$ \\
\hline 27.2 & 440 & 6860 & 25.9 & 30.9 & 17.0 \\
\hline 28.6 & 462 & 7200 & 27.2 & 32.0 & 17.8 \\
\hline 30.0 & 484 & 7550 & 28.5 & 33.5 & 18.6 \\
\hline 31.3 & 506 & 7890 & 29.8 & 35.0 & 19.5 \\
\hline 32.7 & 528 & 8230 & 31.1 & 36.5 & 20.3 \\
\hline 34.0 & 550 & 8580 & 32.4 & 38.0 & 21.2 \\
\hline 35.4 & 572 & 8920 & 33.7 & 39.5 & 22.0 \\
\hline 36.8 & 594 & 9260 & 35.0 & 41.0 & 22.9 \\
\hline 38.1 & 616 & 9600 & 36.2 & 42.6 & 23.7 \\
\hline 39.5 & 638 & 9950 & 37.5 & 44.1 & 24.6 \\
\hline 40.9 & 660 & 10290 & 38.8 & 45.6 & 25.4 \\
\hline 42.2 & 682 & 10630 & 40.1 & 47.1 & 26.3 \\
\hline 43.6 & 704 & 10980 & 41.4 & 48.6 & 27.1 \\
\hline 44.9 & 726 & 11320 & 42.7 & 50.2 & 28.0 \\
\hline 46.3 & 748 & 11660 & 44.0 & 51.7 & 28.8 \\
\hline 47.7 & 770 & 12010 & 45.3 & 53.2 & 29.7 \\
\hline 49.0 & 792 & 12350 & 46.6 & 54.7 & 30.5 \\
\hline 50.4 & 814 & 12690 & 47.9 & 56.2 & 31.4 \\
\hline 51.7 & 836 & 13030 & 49.2 & 57.8 & 32.2 \\
\hline 53.1 & 858 & 13380 & 50.5 & 59.3 & 33.1 \\
\hline 54.5 & 880 & 13720 & 51.8 & 60.8 & 33.9 \\
\hline 55.8 & 902 & 14060 & 53.1 & 62.3 & 34.7 \\
\hline 57.2 & 924 & 14410 & 54.4 & 63.8 & 35.6 \\
\hline 58.6 & 946 & 14750 & 55.7 & 65.4 & 36.4 \\
\hline 59.9 & 968 & 15090 & 57.0 & 66.9 & 37.3 \\
\hline 61.3 & 990 & 15433 & 58.2 & 68.4 & 38.1 \\
\hline 62.6 & 1012 & 15780 & 59.5 & 69.9 & 39.0 \\
\hline 64.0 & 1034 & 16120 & 60.8 & 71.4 & 39.8 \\
\hline 65.4 & 1056 & 16460 & 62.1 & 73.0 & 40.7 \\
\hline 66.7 & 1078 & 16810 & 63.4 & 74.5 & 41.5 \\
\hline 68.1 & 1100 & 17150 & 64.7 & 76.0 & 42.4 \\
\hline 69.5 & 1122 & 17490 & 66.0 & 77.5 & 43.2 \\
\hline 70.8 & 1144 & 17840 & 67.3 & 79.0 & 44.1 \\
\hline 72.2 & 1166 & 18180 & 68.6 & 80.6 & 44.9 \\
\hline 73.5 & 1188 & 18520 & 69.9 & 82.1 & 45.8 \\
\hline 74.9 & 1210 & 18870 & 71.2 & 83.6 & 46.6 \\
\hline 76.3 & 1232 & 19210 & 72.5 & 85.1 & 47.5 \\
\hline 77.6 & 1254 & 19550 & 73.8 & 86.6 & 48.3 \\
\hline 79.0 & 1276 & 19890 & 75.1 & 88.2 & 49.1 \\
\hline 80.3 & 1298 & 20240 & 76.4 & 89.7 & 50.0 \\
\hline 81.7 & 1320 & 20580 & 77.7 & 91.2 & 50.8 \\
\hline 83.1 & 1342 & 20920 & 79.0 & 92.7 & 51.7 \\
\hline 84.4 & 1364 & 21270 & 80.3 & 94.2 & 52.5 \\
\hline
\end{tabular}

Table No.-3(Ratio of Ammonia and $\mathrm{CO}_{2}$ at the feed in time) shall be started to avoid liner damaged so the rate must be maintained at about $30 \mathrm{~kg} / \mathrm{cm}^{2} / \mathrm{hr}$. Open steam to E- 1 by PV14 valve and rise temperature very slowly.

This is the challenging task to feed in the reactor. We have two ammonia High pressures feed pump M/S.Uraca made variable (with torque convertor) capacity $90 \mathrm{~m}^{3} / \mathrm{hr}$. and one small pump M/S. Peroni made having capacity $25 \mathrm{~m}^{3} / \mathrm{hr}$. fixed capacity with recycle valve. In this typical case, we were used small capacity pump for initial and after one hour high capacity pump was taken in line.

\begin{tabular}{|c|c|c|c|c|c|}
\hline $\begin{array}{c}\text { Plant Load } \\
\%\end{array}$ & MTPD & $\begin{array}{l}\mathrm{CO}_{2} \mathrm{~T} 0 \mathrm{R}-1 \\
\left(\mathrm{NM}^{3} / \mathrm{HR}\right)\end{array}$ & $\begin{array}{c}\mathrm{NH}_{3} \mathrm{~T} 0 \mathrm{R}-1 \\
\left(\mathrm{M}^{3} / \mathrm{HR}\right)\end{array}$ & P-1 (RPM) & $\begin{array}{c}\mathrm{NH}_{3} \text { FROM BL } \\
\left(\mathrm{M}^{3} / \mathrm{HR}\right)\end{array}$ \\
\hline 85.8 & 1386 & 21610 & 81.6 & 95.8 & 53.4 \\
\hline 87.2 & 1408 & 21950 & 82.8 & 97.3 & 54.2 \\
\hline 88.5 & 1430 & 22300 & 84.1 & 98.8 & 55.1 \\
\hline 89.9 & 1452 & 22640 & 85.4 & 100.3 & 55.9 \\
\hline 91.2 & 1474 & 22980 & 86.7 & 101.8 & 56.8 \\
\hline 92.6 & 1496 & 23320 & 88.0 & 103.4 & 57.6 \\
\hline 94.0 & 1518 & 23670 & 89.3 & 104.9 & 58.5 \\
\hline 95.3 & 1540 & 24010 & 90.6 & 106.4 & 59.3 \\
\hline 95.6 & 1545 & 24118 & 91.0 & 107.0 & 59.6 \\
\hline 96.5 & 1560 & 24343 & 91.8 & 108.0 & 60.2 \\
\hline 97.4 & 1574 & 24569 & 92.7 & 109.0 & 60.7 \\
\hline 98.3 & 1588 & 24794 & 93.5 & 110.0 & 61.3 \\
\hline 99.2 & 1603 & 25019 & 94.4 & 111.0 & 61.8 \\
\hline 100.1 & 1617 & 25245 & 95.2 & 112.0 & 62.4 \\
\hline 101.0 & 1632 & 25470 & 96.1 & 113.0 & 62.9 \\
\hline 101.9 & 1646 & 25696 & 96.9 & 114.0 & 63.5 \\
\hline 102.8 & 1661 & 25921 & 97.8 & 115.0 & 64.1 \\
\hline 103.7 & 1675 & 26146 & 98.6 & 116.0 & 64.6 \\
\hline 104.6 & 1689 & 26372 & 99.5 & 117.0 & 65.2 \\
\hline 105.5 & 1704 & 26597 & 100.3 & 118.0 & 65.7 \\
\hline 106.4 & 1718 & 26823 & 101.2 & 119.0 & 66.3 \\
\hline 107.3 & 1733 & 27048 & 102.0 & 120.0 & 66.8 \\
\hline 108.2 & 1747 & 27273 & 102.9 & 121.0 & 67.4 \\
\hline 109.0 & 1762 & 27499 & 103.7 & 122.0 & 68.0 \\
\hline 109.9 & 1776 & 27724 & 104.6 & 123.0 & 68.5 \\
\hline 110.8 & 1791 & 27950 & 105.4 & 124.0 & 69.1 \\
\hline 111.7 & 1805 & 28175 & 106.3 & 125.0 & 69.6 \\
\hline 112.6 & 1819 & 28400 & $\begin{array}{l}107.1 \\
\end{array}$ & 126.0 & 70.2 \\
\hline 113.5 & 1834 & 28626 & 108.0 & 127.0 & 70.7 \\
\hline 114.4 & 1848 & 28851 & $\begin{array}{l}108.8 \\
\end{array}$ & 128.0 & 71.3 \\
\hline 115.3 & 1863 & 29077 & 109.7 & 129.0 & 71.9 \\
\hline 116.2 & 1877 & 29302 & 110.5 & 130.0 & 72.4 \\
\hline 117.1 & 1892 & 29527 & 111.4 & 131.0 & 73.0 \\
\hline 118.0 & 1906 & 29753 & 112.2 & 132.0 & 73.5 \\
\hline 118.9 & 1921 & 29978 & 113.1 & 133.0 & 74.1 \\
\hline 119.8 & 1935 & 30204 & 113.9 & 134.0 & 74.6 \\
\hline 120.7 & 1949 & 30429 & $\begin{array}{l}114.8 \\
\end{array}$ & 135.0 & 75.2 \\
\hline 121.6 & 1964 & 30654 & 115.6 & 136.0 & 75.8 \\
\hline 122.5 & 1978 & 30880 & 116.5 & 137.0 & 76.3 \\
\hline 123.4 & 1993 & 31105 & 117.3 & 138.0 & 76.9 \\
\hline 124.2 & 2007 & 31331 & 118.2 & 139.0 & 77.4 \\
\hline 125.1 & 2022 & 31556 & 119.0 & 140.0 & 78.0 \\
\hline \multicolumn{6}{|c|}{ Prem Baboo, Sr. Manager (Prod) } \\
\hline
\end{tabular}

We were using $2^{\text {nd }}$ option we feed first ammonia at slow rate so we used small capacity ammonia feed pump $31 \mathrm{P}-1 \mathrm{C}$ (cap-25 m 3 hr.) after one hr. we have got about $35 \mathrm{~kg} / \mathrm{cm}^{2}$ pressure and after one hr. $\mathrm{CO}_{2}$ fed to reactor and now normal filled reactor feed in conditions achieved.Urea conversion reaction is slow and takes 20 minutes to attain equilibrium. The sufficient pressure is required for urea reaction. Considering the slowness of the reaction, urea reactor is so designed that residence time should be more than 20 minutes. Higher residence time favours equilibrium 
conversion and normally reactors are designed for residence time of 30 minutes to one hour, depending upon other operating parameters. This exothermic reaction is slow at atmospheric pressure and room temperature, but almost instantaneous at a pressure of about $100 \mathrm{~kg} / \mathrm{cm}^{2} \mathrm{a}$ and temperature of $150^{\circ} \mathrm{C}$. Rate of formation of carbamate depends on the temperature and pressure. The rate increases with both temperature and pressure. At constant pressure, the rate increases with temperature, reaches the maximum and then rapidly decreasing up to zero value at the temperature corresponding to which the dissociation pressure equals the working pressure. The heat of formation must be dissipated in order to avoid the increase of temperature which corresponds to a dissociation pressure equal to the working pressure. This is an equilibrium reaction and proceeds only in the liquid or solid phase. Rate of transformation of ammonium carbamate to urea without excess water or ammonia and $\mathrm{NH}_{3}: \mathrm{CO}_{2}$ ratio of $3.5: 1$ indicates that for carbamate conversion to urea increases with temperature. At a temperature of approximately $170^{\circ}$ $\mathrm{C}$, equilibrium is reached within 20 minutes.

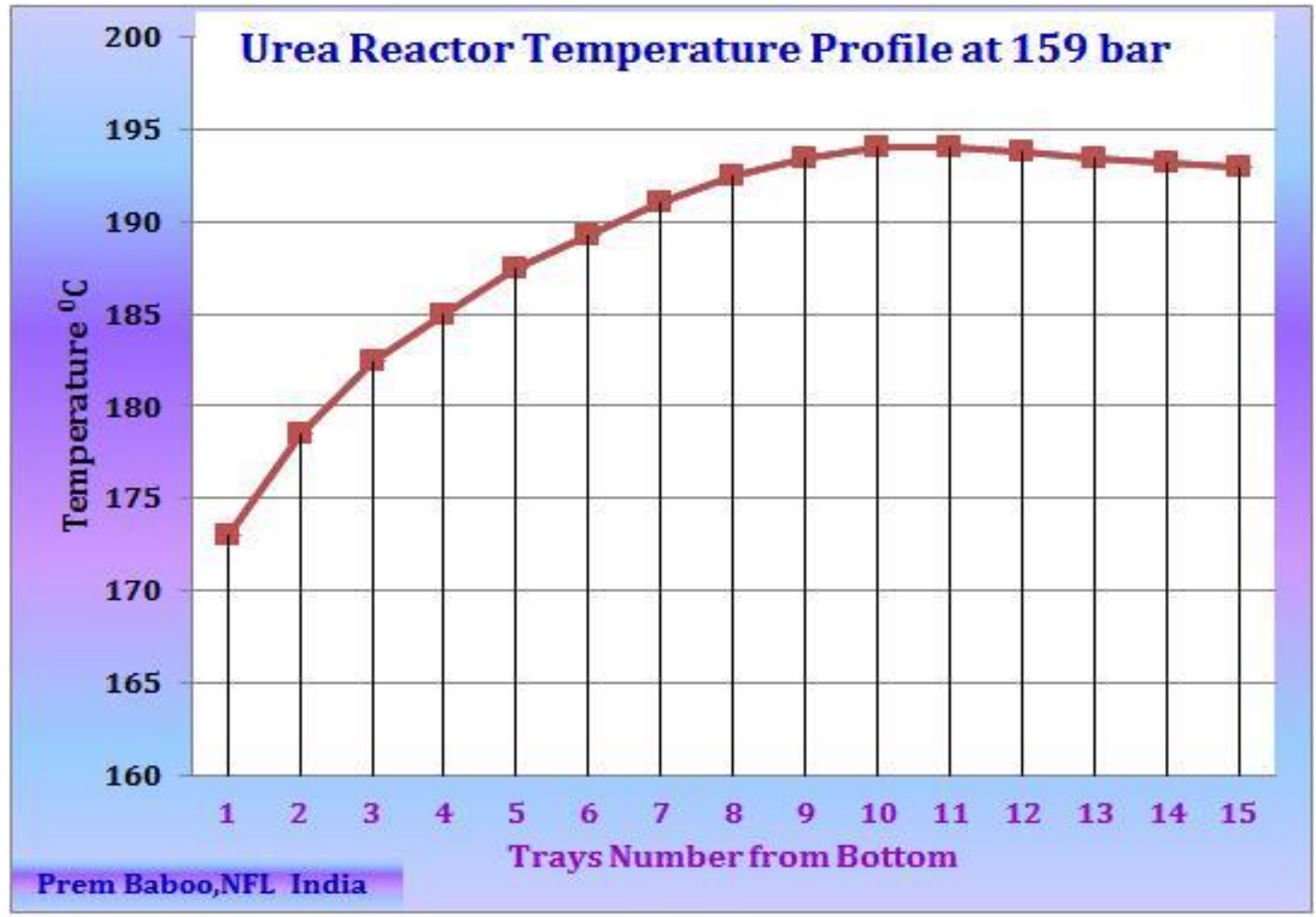

Fig-6(Temperature profile inside the reactors)

Slowly overflow of reactor appeared in stripper bottom and adopted normal rout of plant startup.

How to drain out Urea/Carbamate solution from Urea Reactor at Zero $\mathrm{Kg} / \mathrm{cm}^{2}$ Pressure

In our case the leakage from PSV upstream flange had been arrested successfully but in case if leakage cannot be arrested then how to drain out HP loop solution at zero $\mathrm{kg} / \mathrm{cm}^{2}$ pressure. It is very typical task to handle the effluent generation as well as draining from $1 \frac{1}{2}$ " drain line. From this line there are chances of choking the line frequently.In that case following procedure to be followed as per figure No. 7.

\section{Procedure}

First of all, start up jacketing line which is connected to Stripper vapour line with Isolation and NRV takes in line and medium pressure steam(MS) to be charged. Now HP ammonia Feed pump starts and pressure to maintained at about $50 \mathrm{~kg} / \mathrm{cm}^{2}$ with the help of recycle line. Now ammonia feed to stripper vapour line and temperature of ammonia to be maintained at about $150^{\circ} \mathrm{C}$.The pressure of HP loop gradually increases and when this reaches about 30 $35 \mathrm{~kg} / \mathrm{cm}^{2}$ then draining of HP loop to be started from reactor bottom from $\mathrm{CO}_{2}$ line as shown in the figure-7. total liquid must be drained through this line and pressure of HP loop to be maintained more than MP loop all urea solution collected Urea solution tank(V-5) and carbamate to be collected in carbonate solution tank(V-3). which should be reclaimed when plant normal running condition. As and when solution level becomes zero i.e. opening of LV101(MP level controller) goes to zero then the system to be depressurized through PV-7 B. Now normal route LS purging and job hand over to mechanical maintenance for PSV replacement and leakage attending. There is no man entry so there is no need to filled water. 


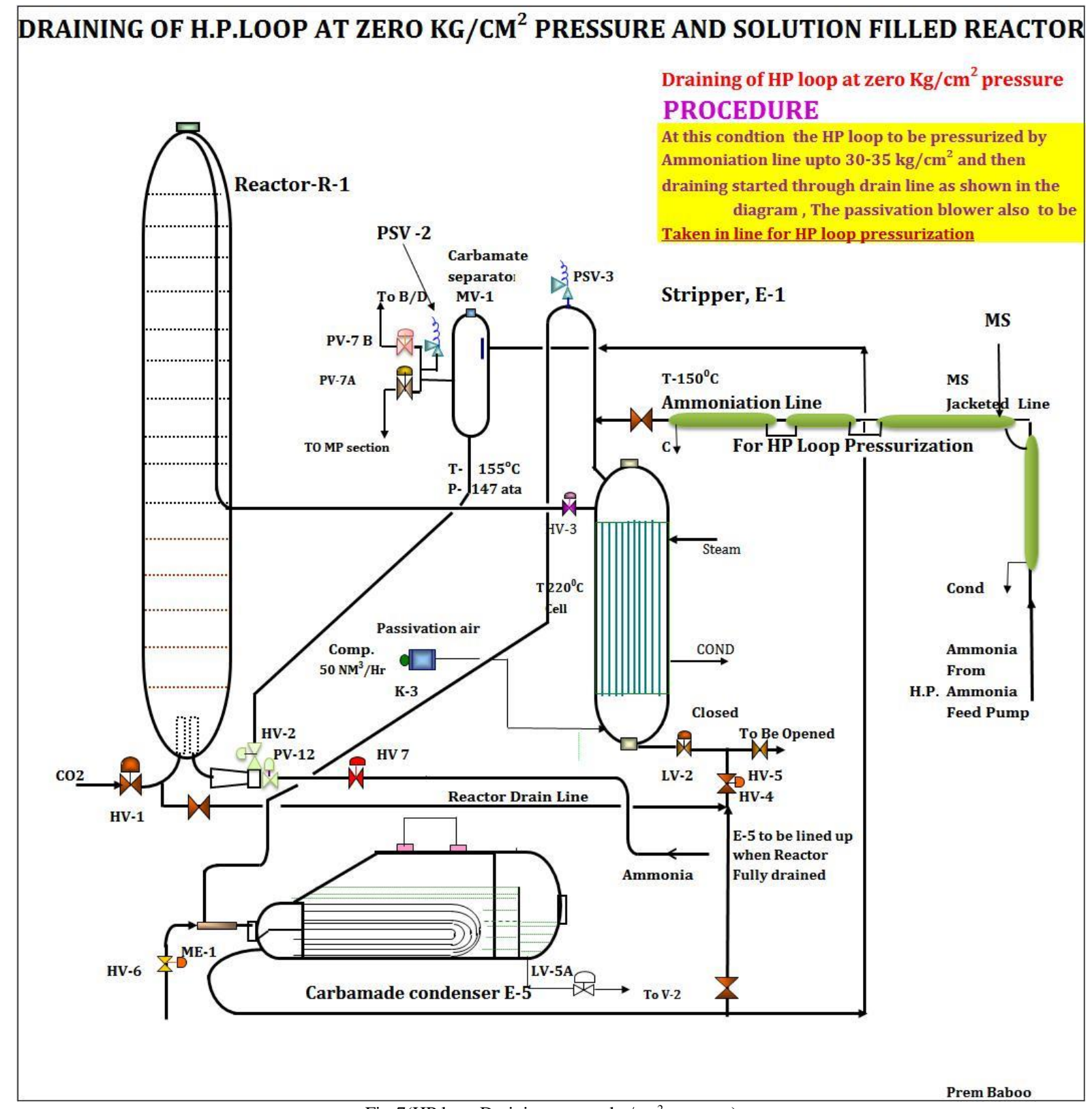

Fig-7(HP loop Draining as zero $\mathrm{kg} / \mathrm{cm}^{2}$ pressure)

Ammonia/carbamate vapour can easily remove with low pressure steam about 3-4 hrs. PPE can be used for this purpose. Ammonia should be checked by opening any vent/drain line, if ammonia smells coming then further LS purging for one hour to be done.
Carbamate PSV monitoring

In practice, all the carbamate PSV d/s steam must be opened in blow down line because in case of PSV passing, carbamate vapour easily crystalized in solid form resulting the $\mathrm{B} / \mathrm{d}$ header will have choked \&lead to line blast. The $\mathrm{B} / \mathrm{D}$ header is not designed for high pressure.So, the steam valve must be checked and opened and lineshould be hot. 


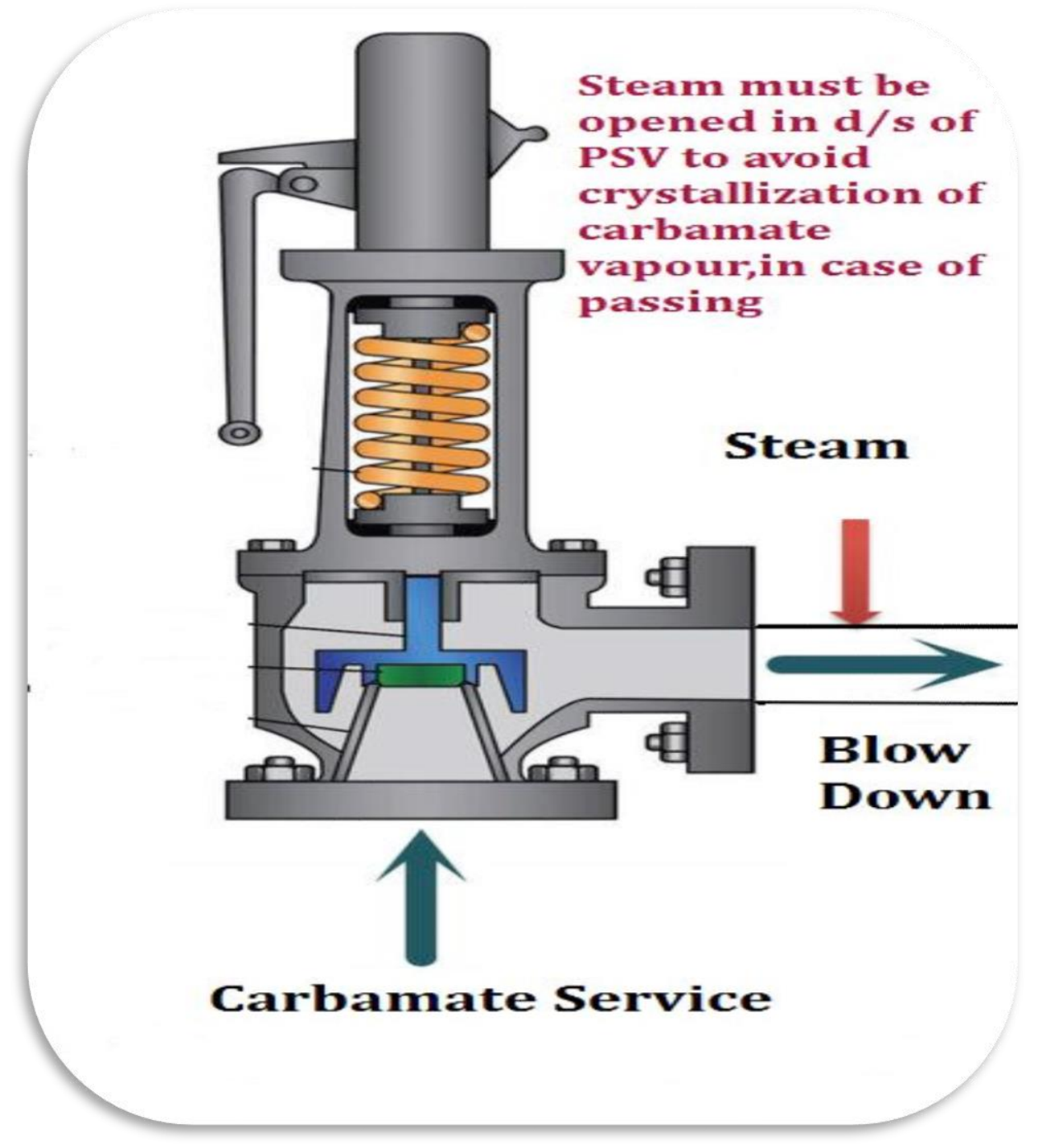

Fig-8 (PSV mounted in HP loop in carbamate vapour)

\section{CONCLUSION}

Safety rules should never be denied. Continuously confirm and share the consensus that "Safety takes precedence over all otherConsiderations," and realize and maintain safe, sanitary conditions in all workplaces.Strive to complete all jobs with no accidents and no harm to people by enforcing preventive safetymeasures.Ammonia is one among the largest volume inorganic chemicals in the chemical process industries and used mainly for production of fertilizers using steam reforming of natural gas. But problems and failures do occurs frequently in the ammonia plant even after following the inherently safer design philosophy and risk assessment. Major areas of concerns/ failures are reforming and urea synthesis loop causing fires/leakages and shutdowns.Ensure information security, and take appropriate safeguards against threats and risks to businessassets. Minimize environmental burden by saving resources and energy, detoxifying, reducing and recyclingwaste, and by preventing pollution during the course of our work duties.Establish and continuously improve the effectiveness of management systems, including objective setting, hazard identification, risk evaluation, determination of countermeasures, execution controland review, and education and training, in line with management system belief that the securement ofHSSE and quality is a prerequisite for business continuity.

\section{Legends-}

HP high pressure, PPE-personal protective equipment's. MW-megawatt, HSSE-health Safety Security and environment.LS-low pressure steam, MS medium (24 bar) steam.B/D-Blow down. 